\title{
DA EFETIVIDADE DECISÓRIA À TRANSFORMAÇÃO SOCIAL: $O$ INVESTIMENTO INSTITUCIONAL EM COORDENAÇÃO, MONITORAMENTO E TRANSPARÊNCIA COMO PEÇA-CHAVE PARA A MODERNIZAÇÃO DA PRESTAÇÃO JURISDICIONAL
}

\author{
FROM DECISION-MAKING EFFECTIVENESS TO SOCIAL \\ TRANSFORMATION: INSTITUTIONAL INVESTMENT IN \\ COORDINATION, MONITORING AND TRANSPARENCY AS A KEY \\ ELEMENT FOR THE MODERNIZATION OF JURISDICTIONAL \\ PROVISION
}

\begin{abstract}
Recebimento: 3 set. 2020
Aceitação: 27 jan. 2021

Karina Denari Gomes de Mattos

Doutora em Direito

Afiliação institucional: Universidade Federal do Rio de Janeiro - UFRJ - (Rio de Janeiro, RJ, Brasil)

Lattes iD: http://lattes.cnpq.br/0763664903829681

Email: karinadenari@gmail.com

Vanice Regina Lírio do Valle

Doutora em Direito

Afiliação institucional: Universidade Estácio de Sá (Rio de Janeiro, RJ, Brasil)

Lattes iD: http://lattes.cnpq.br/3362470177133456

Email:vanicevalle@gmail.com
\end{abstract}

\begin{abstract}
Como citar este artigo / How to cite this article (informe a data atual de acesso / inform the current date of access):
MATTOS, Karina Denari Gomes de; VALLE, Vanice Regina Lírio do. Da efetividade decisória à transformação social: o investimento institucional em coordenação, monitoramento e transparência como peça-chave para a modernização da prestação jurisdicional. Revista da Faculdade de Direito UFPR, Curitiba, v. 66, n. 2, p. 185-212, maio/ago. 2021. ISSN 2236-7284. Disponível em: https://revistas.ufpr.br/direito/article/view/76271. Acesso em: 31 ago. 2021. DOI: http://dx.doi.org/10.5380/rfdufpr.v66i2.76271.
\end{abstract}

\section{RESUMO}

O presente trabalho intenciona demonstrar que, para aperfeiçoar seu papel institucional no século XXI, o Poder Judiciário precisa dedicar maior esforço institucional à prestação de contas e à accountability decisória. Três focos de ação complementares são necessários: i) ampliação de iniciativas interinstitucionais estratégicas (coordenação), ii) construção de mecanismos de monitoramento decisório capazes de contemplar a sociedade civil (monitoramento) e iii) viabilização de um amplo acesso à informação a respeito desses dados e iniciativas (transparência). Pelo uso da metodologia de análise do Direito Constitucional comparado, conclui-se que o Poder Judiciário brasileiro reúne condições institucionais e as ferramentas operacionais para promover tais inovações, a partir do incremento estratégico e tecnológico de iniciativas já conduzidas pelo Conselho Nacional de Justiça (CNJ). Ressalta-se aqui a importância de uma política judiciária brasileira que olhe para o 
momento pós-decisório, a partir da incorporação de boas práticas de outros países, as quais possam orientar a maior inserção desse tema de pesquisa no Brasil e na América Latina.

\title{
PALAVRAS-CHAVE
}

Poder Judiciário. Coordenação institucional. Prestação de contas. Monitoramento judicial.

\begin{abstract}
This paper intends to demonstrate that, in order to improve its institutional role in the 21st century, the Judiciary branch needs to devote greater institutional effort to accountability, including the one related to decision-making. Three complementary focuses of action are needed: $i$ ) expansion of strategic inter-institutional initiatives (coordination), ii) construction of decision-monitoring mechanisms capable of contemplating civil society (monitoring) and iii) feasibility of broad access to information about these data and initiatives (transparency). Through a comparative constitutional law analysis, it is concluded that the Brazilian Judiciary brings together institutional conditions and operational tools to promote such innovations, based on the strategic and technological increment of initiatives already conducted by the National Council of Justice (CNJ). The importance of a Brazilian judicial policy that looks to the post-decision-making moment is highlighted here, based on the incorporation of other countries' good practices, which can guide the greater insertion of this research theme in Brazil and Latin America.
\end{abstract}

\section{KEYWORDS}

Judiciary branch. Institutional coordination. Decision-making accountability. Judicial monitoring.

\section{INTRODUÇÃO}

No primeiro semestre de 2019, o Conselho Nacional de Justiça (CNJ) e o Conselho Nacional do Ministério Público (CNMP) lançaram uma plataforma conjunta para monitoramento de casos de grande repercussão, o chamado Observatório Nacional sobre Questões Ambientais, Econômicas e Sociais de Alta Complexidade e Grande Impacto e Repercussão (em diante, Observatório).

O Observatório, que possui caráter nacional e permanente, tem a atribuição de promover integração institucional, elaborar estudos e propor medidas concretas de aperfeiçoamento do sistema nacional de justiça, nas vias extrajudicial e judicial, para enfrentar situações concretas de alta complexidade, grande impacto e elevada repercussão social, econômica e ambiental (CONSELHO NACIONAL DE JUSTIÇA; CONSELHO NACIONAL DO MINISTÉRIO PÚBLICO, 2020). Para o desenvolvimento da dimensão propositiva uma das ferramentas eleitas foi o estudo de caso, fonte para a indicação de iniciativas exitosas e de gargalos institucionais ou operacionais à concretização da prestação jurisdicional.

O então Presidente do Conselho Nacional de Justiça e do Supremo Tribunal Federal, ministro Dias Toffoli, na sua cerimônia de lançamento, apresentou o que esperava da iniciativa e reforçou: “[O Observatório] é para observar a nós mesmos. É nos colocarmos diante do espelho e 
olharmos: é essa a justiça que queremos para a sociedade? Para as vítimas de Brumadinho e de Mariana, pais e mães das vítimas da Boate Kiss e para as viúvas de Unaí?”, questionou, e lembrou a obrigação do sistema de justiça em dar uma resposta à sociedade (LANÇADO..., 2019).

A amostra de casos selecionada pelo Observatório é significativa por vários aspectos. Primeiramente, pela razão técnica de constituírem casos de complexo tratamento - que envolvem atores públicos e privados numa intrincada teia de relações para a reparação dos danos e prevenção de novos casos. Contando com diferentes estratégias de composição de litígios e distintos perfis de grupos atingidos ${ }^{1}$, os episódios ilustram a diversidade de vetores que podem se combinar para a construção de uma prestação jurisdicional apta a oferecer resposta aos litigantes e, ainda, à sociedade.

O presente trabalho, em sintonia com a iniciativa apontada, argumenta que o Judiciário precisa dedicar maior esforço institucional à prestação de contas e accountability decisória. Nessa linha, defende-se que o Poder Judiciário brasileiro reúne condições institucionais e ferramentas operacionais para capitanear um projeto inovador diretamente voltado à ampliação da efetividade judicial, por meio da implementação de melhores mecanismos de monitoramento decisório e um sistema de prestação de contas mais eficaz, especialmente por seu órgão de cúpula, o Supremo Tribunal Federal (STF).

Na perspectiva deste artigo, a prestação de contas e a demonstração da efetividade decisória são o resultado de três operações complementares: $i$ ) a ampliação de iniciativas interinstitucionais estratégicas, a exemplo do Observatório (coordenação), ii) a construção de mecanismos de monitoramento decisório capazes de contemplar a sociedade civil (monitoramento), e iii) a viabilização de um amplo acesso à informação a respeito desses dados e iniciativas (transparência).

O presente artigo será desenvolvido em três partes. A primeira delas oferece a problematização, objeto, objetivo e demais elementos metodológicos. A segunda parte pretende apresentar como a literatura e o Judiciário norte-americanos procuraram tratar do problema da implementação de decisões judiciais e as lições que podem ser aproveitadas desse aprofundamento teórico e empírico sobre o tema há mais de meio século. A terceira parte desenvolve, a partir da experiência estrangeira, propostas práticas em três eixos essenciais ao desenvolvimento de uma política institucional de transparência e efetividade decisória para a realidade brasileira.

1 Composições extrajudiciais (Barragem de Fundão, nos termos do TTAC de 2016, e sucessivos acordos TAP e TAPAditivo 2017 e TAC-Gov 2018 no âmbito de duas ações civis públicas, a ACP nº 0023863-07.2016.4.01.3800 e a ACP nº 0069758-61.2015.4.01.3400) e composição judicial (Boate Kiss, Unaí, Brumadinho). Mais recentemente, o Observatório passou a acompanhar também a atuação judicial relacionada aos seguintes temas: refugiados, segurança pública, Caso Pinheiro, PPI da Amazônia e indígenas, além de monitorar dados públicos, atos normativos e ações judiciais do coronavírus - covid19 (CONSELHO NACIONAL DE JUSTIÇA, 2020). 
A premissa para o desenvolvimento do argumento do texto é a compreensão de que o Judiciário no século XXI se tenha reconfigurado no que toca à sua função principal, que não mais se reporta a uma visão individualista da solução do conflito localizado, mas sim a uma atuação que tenha como inspiração a garantia, no sentido mais amplo da palavra, de novas dimensões do que se possa entender seja reclamado por um regime democrático. É o que se passa a expor.

\section{RECONFIGURAÇÃO DO JUDICIÁRIO COMO GARANTIDOR DE NOVAS DIMENSÕES DA OPÇÃO DEMOCRÁTICA}

Na perspectiva deste artigo, a construção do Observatório no ano de 2019 e a preocupação externada pelo então Presidente do STF e do CNJ, Dias Toffoli, de “dar uma resposta para a sociedade”, atendem a um movimento internacional relativamente recente e cada vez mais importante de aproximação do Poder Judiciário com a opinião pública e de prestação de contas sobre a dimensão da efetividade de suas decisões (LANÇADO..., 2019).

A preocupação de Dias Toffoli se soma à de outros julgadores em todo o mundo em um momento que estas estruturas experimentam grande visibilidade e poder e, com isso, instabilidade e risco político. Com a consolidação dos sistemas judiciais modernos e com a relativa estabilização dos Estados democráticos constitucionais ${ }^{2}$ o Poder Judiciário se legitima e se fortalece enquanto mediador relevante ${ }^{3}$ das disputas políticas e sociais nas democracias. Cortes constitucionais contemporâneas prestam contas à sociedade também porque dependem da opinião pública para ampliar seus níveis de legitimidade e manter sua autoridade e independência diante dos demais atores políticos. Todavia, a opinião pública confia no Judiciário à medida que avalia como positivo seu impacto e sua capacidade de transformação social.

Em países com períodos recentes de estabilidade política, as cortes se sentiram confortáveis em experimentar decisões que avançam mais na garantia de direitos e liberdades. Em contextos políticos mais conturbados outras tiveram que se posicionar para, quando menos, fazer frente a ameaças às garantias já conquistadas. Em que pesem divergências sobre como e em que medida são admitidas intervenções judiciais em deliberações políticas estruturais, não se pode negar que as cortes

2 Se não considerados os estudos sobre declínio democrático (“democracy decay”) e suas recentes conceitualizações (DALY, 2019).

3 A ideia de mediação de conflitos constitucionais está presente na obra “Constitutional Courts as Mediators” (RÍOSFIGUEROA, 2016) e é detalhada, para o Brasil, como a concentração de poderes na esfera judicial brasileira sob o conceito de "supremocracia”, defendido por Vilhena Vieira (2018). Na América Latina, a ideia de mediação política das instituições judiciais é ressaltada no artigo de Fabiano Engelmann e Júlia Bandeira (2017, p. 199). 
ocupam hoje um espaço central na delimitação dos contornos político-institucionais das democracias contemporâneas.

Issacharoff (2015) defende que o uso do constitucionalismo acompanhado pelo papel central de cortes constitucionais emergiu como o principal mecanismo de gestão de conflitos nos diversos contextos nacionais da maioria das democracias no mundo ${ }^{4}$. Este seria o grande desafio das democracias "frágeis", que surgem na terceira onda democratizante ${ }^{5}$ pela superação de passados autoritários em uma sociedade ainda dividida, mas que devem lidar com um dilema que está nas entranhas de todas as democracias liberais bem-sucedidas: elas devem permitir a regra majoritária ao mesmo tempo que a limita (ISSACHAROFF, 2015, p. 2).

A complexidade inerente a essa nova forma de oferta da jurisdição mudou o paradigma de desenvolvimento da função, principalmente, no que toca às expectativas quanto a seus resultados práticos. Conflitos judicializados hoje podem apresentar uma diversidade de interessados (postulantes, participação de amicus curiae, audiências públicas e terceiros interessados), multiplicidade de virtuais destinatários da decisão (órgãos públicos, privados, entidades do terceiro setor) e ainda uma variedade de postulações quanto ao conteúdo decisório propriamente (inserção cada vez maior de temas de direito coletivo e interesse público, nas tutelas de direitos das comunidades e populações marginalizadas) ${ }^{6}$.

A mediação institucional e a vocalização dos valores constitucionais subjacentes aos regimes democráticos nos embates mais caros à manutenção dessa mesma ordem têm aproximado o Poder Judiciário da opinião pública, tornando-o mais suscetível ao “canto da sereia” das ruas. Nada garante que o posicionamento popular estará sempre alinhado com os valores constitucionalmente assegurados e, por isso, o Judiciário deve manter sua prerrogativa de confrontar tecnicamente a posição majoritária - sem, com isso, perder parcela de sua autoridade e o respeito às suas decisões.

Para lidar com a dificuldade contramajoritária decisória e a necessidade de legitimidade social em tempos de instabilidade e crise democrática, como já se disse, desponta a importância de reforço da accountability do processo decisório, em seus vários momentos. Explorando esse viés, há

4 Essa tarefa é especialmente desafiadora no que ele chamou de "sociedades fraturadas”, caracterizadas por persistentes animosidades raciais, étnicas ou religiosas, em que instituições multirraciais e multiétnicas são pouco desenvolvidas ou não existem (ISSACHAROFF, 2015, p. 10).

5 A terceira onda pode ser tida como a pós-transição democrática ocorrida a partir de 1974 com a Revolução dos Cravos em Portugal, nos países do leste europeu e América Latina (aproximadamente 30 países), e que foi o período de maior incorporação de nações à democracia, mudando o perfil dos sistemas políticos contemporâneos (HUNTINGTON, 1994).

6 Quanto mais atores forem credenciados a usar o Judiciário, mais temas puderem ser judicializados e mais instrumentos processuais estiverem disponíveis aos atores, maior será a probabilidade de que a política seja judicializada (MOLHANO RIBEIRO; WERNECK ARGUELHES, 2019, p. 10). 
experiências latino-americanas sobre o desenvolvimento de estruturas dedicadas à jurisdição de seguimento e de criação de mecanismos processuais de registro e sanção do descumprimento decisório que merecem atenção por parte da experiência nacional, como se verá a seguir. Além disso, para que a efetividade decisória seja acompanhada de perto pela sociedade, é necessário o levantamento dos dados estatísticos sobre o cumprimento judicial, com a diversificação de fontes de coleta e tratamento, além da incorporação de iniciativas ad hoc de monitoramento bem-sucedidas em outros países.

A iniciativa de investir na accountability do processo decisório, especialmente em conflitos de alta complexidade, é relevante porque dialoga com a sempre presente discussão em torno das estratégias adequadas de garantia da eficácia de direitos socioeconômicos, dos fenômenos da judicialização da política e politização da justiça e sua contribuição para a normalidade democrática, da capacidade institucional do Poder Judiciário para a composição desses conflitos, da participação social e legitimidade judicial decisória no controle das políticas públicas. Ainda, dado que o monitoramento decisório e a efetividade de cumprimento de ordens judiciais são temas que possuem cada vez mais destaque na literatura internacional, com ainda relativo escasso investimento na doutrina nacional, é urgente que essa discussão seja incorporada e tratada no Brasil.

Cumpre dizer que, nos Estados Unidos, o início da discussão sobre o desafio de implementação de decisões judiciais remonta a estudos e práticas nos anos de 1950. A Suprema Corte norte-americana e a literatura que se seguiu às inovações experimentadas nesse período, inauguradas pelo célebre julgamento Brown v. Board of Education (ESTADOS UNIDOS DA AMÉRICA, 1954), foram determinantes para a criação de um campo de pesquisa que se ocupasse da implementação de julgados (implementation problem) como algo central em decisões que envolvem políticas públicas. É útil, portanto, compreender como se deu, naquela experiência, o desenvolvimento da proposta aqui veiculada, de incremento da accountability decisória no exercício da jurisdição.

\section{O PROBLEMA DA IMPLEMENTAÇÃO E SUA ORIGEM NORTE-AMERICANA}

Na sua origem, o desenho institucional do Poder Judiciário norte-americano foi desenvolvido de forma que este fosse o mais fraco dos poderes, conforme clássico trecho dos Federalistas 78, de Hamilton. A literatura convencionou chamar essa caraterística, pela perspectiva de seu órgão de cúpula, de Constrained Court. Essa descrição, inicialmente, amoldou-se à sua 
atuação, que foi caracterizada como impotente; sendo certo que quando, saindo deste modelo, ela se revelou ativa, viu-se rechaçada e sancionada politicamente (HALL, 2011, p. 3).

A própria natureza do judicial review nos EUA contribuiu para o papel tímido de seu Tribunal Constitucional. Por não deter o monopólio da jurisdição constitucional e de realizar análise em concreto dos casos que chegam até ela, a Suprema Corte norte-americana enfrenta um desafio de implementação que depende da aceitação e obediência de tribunais inferiores, no âmbito dos seus estados federativos. Além disso, dado que suas decisões geram efeitos inter partes, mesmo com o uso da doutrina do stare decisis (que dá à decisão o efeito de um precedente vinculante), tais limitações geram um desafio adicional de impacto decisório.

O cenário muda a partir dos anos de 1950, momento em que se inaugura uma profunda transformação política do Tribunal, sob a liderança das Cortes Warren e Burger, ao decidir temáticas como relações raciais, liberdades civis, direito criminal, administração das prisões, representação política, regulação ambiental, privacidade e, inclusive, o papel da religião na sociedade (HALL, 2011, p. 4). Em especial, a decisão de Brown v. Board of Education, em 1954, que determinou a política de dessegregação escolar no país, representa o marco divisor da postura deste órgão na dinâmica dos poderes.

Tushnet (1992, p. 25), nessa linha, indica que a preocupação da Corte com os casos de reforma da composição racial nas escolas deu início ao que se convencionou chamar de "public law litigation”, ou seja, uma forma mais “agressiva” de judicial review. Para este autor, o caso Brown vai ter na verdade duas dimensões igualmente importantes: uma de mérito - interpretando a Constituição no sentido de que escolhas administrativas não poderiam levar em consideração o critério racial - e outra quanto à espécie de provimento jurisdicional - relacionado não só à enunciação de dever passivo (não segregação), mas fixando ainda a existência de um dever ativo, de integração, do Estado (TUSHNET, 1992, p. 23). Essa segunda característica da decisão foi central para que seu objetivo não fosse driblado por alternativas criadas pelos estados que resistiram ao julgado. Seu segundo efeito positivo foi impulsionar o Poder Judiciário ao desenvolvimento de uma expertise relacionada com a implementação de suas decisões.

Friedman (2016, p. 48) acrescenta que o que atribui ao caso Brown sua relevância não é exclusivamente a prolação do mandamento que impõe o fim da segregação escolar nas escolas públicas dos Estados Unidos, mas todo o movimento de direitos civis que foram reforçados por este julgado. Um resultado muito importante foi a sensível mudança na atmosfera nacional sobre as relações de raça, com evidente declínio do prestígio à corrente de “supremacia branca”, inclusive no sul do país. O movimento de mobilização jurídica que decorreu dessa abertura interpretativa da 
Suprema Corte norte-americana fomentou o surgimento de um novo campo de pesquisa sobre a mobilização social do direito, ou “legal mobilization”.

Após o leading case, outras decisões judiciais da Corte Warren mantiveram o perfil decisional estrutural, em áreas como a reforma dos sistemas prisionais, a administração de hospitais de saúde mental, a reforma da composição racial das escolas, esforços para proteção ambiental e políticas de moradia e habitação (EASTON, 1990, p. 1.983-1.984). Foi nesse período que os estudos de efetividade decisória e cumprimento decisório (compliance judicial) ${ }^{7}$ começaram a despertar nos Estados Unidos, junto aos trabalhos relacionados à mobilização “do” e “pelo” direito.

Por isso, defende-se que a decisão Brown desperta toda uma rede de produção acadêmica e novas práticas judiciais a respeito dos desafios de se implementar e cumprir decisões - por sua complexa articulação interinstitucional que envolve Judiciário e demais poderes, pelos desafios impostos pela hierarquia judicial norte-americana, ou, ainda, na sua relação com a sociedade. Uma farta literatura se seguiu à decisão de Brown, criando as classificações e as categorizações judiciais para a compreensão do fenômeno e suas especificidades, composta de estudos provenientes do Direito, mas também de outros campos, como a Ciência Política, a Psicologia (com o início dos estudos comportamentais no período), a Sociologia Jurídica e a Economia ${ }^{8}$.

Em especial, a Ciência Política teve importante papel na consolidação de uma nova visão sobre o Judiciário norte-americano, momento em que estudos passaram a se dedicar a aprofundar como se dá a relação do Judiciário, especialmente pelo modelo espacial de Separação de Poderes (SOP), e como esse relevante ator incorpora elementos estratégicos na sua atuação em relação aos demais atores políticos - para além das preferências ideológicas do modelo atitudinal previamente analisadas $^{9}$. Por isso, a literatura de comportamento judicial é considerada a ponte entre o mundo do Direito Público e da Ciência Política (MAVEETY, 2002, p. 4) e tal interdisciplinaridade tornou-se a marca das pesquisas que procuram entender e sistematizar o conhecimento sobre o campo, especialmente a partir dos anos de 1950.

7 O trabalho considerado referência no tema é o de Kapiszewski e Taylor (2013), que propõe ferramentas de conceitualização e métrica do compliance judicial, e reconhece que os EUA foram os precursores do desenvolvimento de parâmetros de cumprimento decisório (KAPISZEWSKI; TAYLOR, 2013, p. 805).

8 Lawrence Baum (2003, p. 172) cita os estudos de diversos campos do conhecimento que documentam o que as notícias de jornal já davam na época: a resistência social ao cumprimento da decisão Brown v. Board of Education especialmente nos estados do “Deep South”, tais como as obras de Numan V. Bartley (1969), “The rise of massive resistance: Race and politics in the South during the 1950's”, e de Jack W. Peltason (1971), “Fifty-Eight Lonely Men: Southern Federal Judges and School Desegregation”.

9 Para uma clarificação das diferentes interpretações da literatura na análise estratégica da Suprema Corte, recomendase artigo de Barnes (2007, p. 28-29, tradução nossa), que identifica os “jogos de separação de poderes" ("separationof-powers games”), os “estudos de política de regime” (“regime politics studies”) e a "análise microinstitucional” (“microinstitutional analysis”) como as principais. 
A título de exemplo, há trabalhos que analisam o cumprimento e a efetividade de ordens judiciais a partir de uma perspectiva sociológica, ou sobre como a decisão transforma o indivíduo que a acessa (JOHNSON, 1967; MUIR JR., 1967). Lawrence Baum (2003, p. 172) cita diversos estudos que documentam o que as notícias de jornal já davam na época: a resistência social ao cumprimento da decisão Brown v. Board of Education, especialmente nos estados do “Deep South”. Todavia, mesmo com os avanços modernos sobre esse corpo de literatura, constata-se a existência de informações ainda limitadas sobre o impacto social das decisões da Suprema Corte e muitas interpretações possíveis. A cadeia de causalidade entre uma decisão judicial e o fenômeno social é complexo, então, isolar o impacto da decisão da Corte de outras forças é, em si, problemático. A tarefa normalmente trabalha com exercício contrafactual - ou seja, o que aconteceria se a Corte não tivesse agido? E tal exercício muitas vezes é difícil, se não impossível. Para Baum (2003, p. 176), ainda não existem ferramentas analíticas suficientes para se fazer uma análise do impacto social de intervenções judiciais.

Em uma segunda linha de literatura, focada na burocracia (na relação com o governo, portanto), diversos trabalhos desafiam o senso comum de cortes como producentes de boas políticas (HOROWITZ, 1977). Para Baum (2003, p. 176), esse enfoque Judiciário-governo também vai se mostrar dificultoso. Ainda que haja dados suficientes para se concluir que cortes sofrem de fraquezas quanto à sua capacidade institucional diante da burocracia, não há clareza quanto aos limites e as potencialidades da ação conjunta para mudar a sociedade e ter impacto. Dessa forma, não há também ferramentas analíticas suficientes para a compreensão dos limites e da interação possível entre burocracia e cortes na delimitação de políticas com impacto social.

Por fim, há uma terceira linha de estudos sobre a relação entre órgãos de cúpula e órgãos de implementação de decisões - instâncias inferiores -, com inúmeros trabalhos que se dedicam ao estudo do compliance “intercortes”, como as referências Bradley C. Canon (1973) e Lawrence Baum (1976).

Canon (1973, p. 111) é uma referência no tema, com diversos trabalhos publicados neste período, e no paper exploratório de 1973 o autor analisa as reações das supremas cortes estaduais a uma decisão específica da Suprema Corte norte-americana sobre liberdades civis (decisão Mapp v. Ohio, de 1961) e conclui que existe um fenômeno chamado de "incorporação seletiva” dos julgados da Corte, ou seja, a previsão de que tribunais inferiores não seguem “a letra fria” ou mesmo o espírito dos julgamentos da Corte. O autor afirma que as hipóteses que melhor explicam as variações dizem respeito a diferenças na “cultura regional político-jurídica” (CANON, 1973, p. 130), e indica que para a análise de cumprimento valeria a intensificação dos estudos sobre qual o posicionamento político 
anterior da corte estadual em análise e sobre as características da decisão (lógica, persuasão) como variáveis importantes para sua implementação nos estados (CANON, 1973, p. 131).

O trabalho de Baum, como já referenciado acima, contribui especialmente para a delimitação do campo de estudo, trazendo a ideia de que, apesar de classificadas como “judicial impact”, a amplitude e fraqueza desse termo induz ao melhor uso de "judicial implementation" como termo mais preciso para o campo de pesquisa (BAUM, 1976, p. 87), além de indicar a teoria organizacional como um profícuo caminho para a análise da implementação em estruturas hierarquizadas.

Este primeiro grupo de acadêmicos que inaugurou o estudo do tema entre os anos de 1950 e 1970 lançou as bases de uma profícua agenda de estudos que se desenvolve até hoje nos Estados Unidos $^{10}$. Como indicado previamente, dado o modelo de controle de constitucionalidade norteamericano, a interação entre Suprema Corte e cortes estaduais na implementação é um objeto de estudo com forte investimento por parte da academia.

Matthew Hall (2014) também leva em consideração as hipóteses que vinculam o conteúdo da decisão ao seu cumprimento e reforça que forças externas e o contexto institucional têm um papel relevante na constrição das decisões da Suprema Corte. Segundo a tese colocada, juízes têm medo do não cumprimento decisório e, por isso, desfrutam de maior independência quando o não cumprimento é improvável, ou seja, nos casos em que o implemento depende de atores não judiciais. Isso significa que, nos casos dependentes de instâncias inferiores, as cortes detêm maior compliance decisório ${ }^{11}$.

Por todo o exposto, Lawrence Baum (2003, p. 163), ao fazer um balanço sobre os estudos de impacto, avalia que a literatura norte-americana já avançou bastante sobre o comportamento judicial diante de tais desafios de implementação, especialmente a literatura que analisa o Judiciário ante os demais poderes ${ }^{12}$. Mas destaca que ainda permanece como uma questão aberta nos Estados Unidos a proporção em que juízes agem estrategicamente.

Apresentados os modelos explorados pela literatura norte-americana, cabe verificar como esse mesmo tema - da avaliação do cumprimento da decisão judicial, especialmente em demandas de alta complexidade - se coloca no Brasil.

10 Como exemplo, o denso estudo de Chad Westerland et al. (2010), que dialoga com Canon (1973) a respeito de um fluxo contínuo de troca de experiências entre Suprema Corte e instâncias inferiores, na experiência prática das decisões, e a lógica do "aprendizado judicial” (“judicial learning”) - regra aplicável no estudo da interação entre precedentes das cortes e sua adoção por instâncias inferiores (WESTERLAND et al., 2010, p. 903).

11 A diferenciação dos casos é mais bem aprofundada no livro “The Nature of Supreme Court Power” (HALL, 2011).

12 Essa literatura que analisa as cortes na interação com os demais poderes e com a sociedade qualifica o funcionamento real da política norte-americana. Ao mesmo tempo, permite ampliar a compreensão sobre as forças que moldam a política judiciária e seu impacto (BAUM, 2003, p. 177). 


\section{EFETIVIDADE DECISÓRIA NO BRASIL}

Se nos Estados Unidos a literatura sobre efetividade decisória e cumprimento judicial (compliance judicial) já está bastante avançada, no Brasil e em outras recentes democracias o início dessa agenda se deu de forma bem mais tardia.

Foi apenas ao longo das últimas três décadas que o gradual processo de complexificação das tutelas e dos mecanismos utilizados, a natureza das garantias e direitos em litígio e o uso político do tribunal pelos seus próprios atores ampliaram o fenômeno da judicialização ${ }^{13}$ da política e das relações sociais - o que traz subsídios para o estudo sobre a implementação de decisões nas ciências sociais brasileiras.

Sobre esse ponto, dentre as variadas formas de pesquisa realizadas no Brasil sobre o fenômeno da judicialização, a maior parte corrobora a constatação da presença do Judiciário na arena política e sua interação com os demais atores de instituições majoritárias - tanto na implementação de políticas públicas quanto por sua intervenção na macroestratégia de gestão política. Na sua maioria, os trabalhos tratam da judicialização das relações sociais e da judicialização da política, utilizando como fenômeno de análise as Ações Diretas de Inconstitucionalidade (ADIs) pósConstituição de 1988 ajuizadas no STF, como é o caso da obra “A judicialização da política e das relações sociais no Brasil” (WERNECK VIANNA et al., 1999), a qual é referência no tema e simboliza o início do movimento das ciências sociais no Brasil quanto à investigação do fenômeno (MOLHANO RIBEIRO; WERNECK ARGUELHES, 2019, p. 5).

Em revisão de literatura sobre o tema, Luciano da Ros (2017) apresenta um balanço acurado e crítico sobre a produção acadêmica na área, reconhecendo que, embora muito tenha sido produzido sobre o conceito de judicialização da política no País, esse debate ainda é frequentemente binário, ou mesmo normativo (DA ROS, 2017, p. 58).

Da Ros (2017, p. 59) afirma que apesar de a literatura desenvolvida no Brasil se avolumar, ainda há relativa carência de trabalhos que discutam modelos bastante difundidos na literatura comparada a respeito de construção institucional (insurance model, hegemonic preservation thesis) e de comportamento decisório individual (modelos attitudinal, strategic e institutional) no âmbito da Corte Suprema brasileira: "De forma mais ampla, parece haver um contraste entre a elevada atenção acadêmica concedida ao STF, por um lado, e o leque relativamente minguado de abordagens teóricas empregadas em seu exame, por outro” (DA ROS, 2017, p. 85).

\footnotetext{
13 No sentido mais frequentemente assumido nos estudos brasileiros, a judicialização da política se refere à transferência de decisões normativas, das arenas majoritárias para o Poder Judiciário e, sobretudo, para o STF (MOLHANO RIBEIRO; WERNECK ARGUELHES, 2019, p. 9).
} 
Segundo Da Ros, grande parte da literatura brasileira produz estudos sobre acesso e implementação dos julgados do $\mathrm{STF}^{14}$, mas, sobretudo, quando se analisa o impacto político do Tribunal $^{15}$. Sobre esse impacto, dado o diagnóstico equivocado, de grande parte da literatura no País, acerca de seu caráter diminuto no STF, Da Ros (2017, p. 83) sugere, como aperfeiçoamento da literatura de judicialização no Brasil, entre outros pontos, que "se examinem concretamente os diferentes ritmos de implementação dos julgados da Corte”, além do exame do impacto indireto em etapas anteriores ao processo decisório (definição de problemas, formação de agenda e especificação de alternativas).

Verifica-se da revisão de literatura de Da Ros a necessidade de que as pesquisas e metodologias desenvolvidas para análise de impacto decisório no País também considerem diferenças de processos decisórios, integração do Tribunal nas pesquisas de elaboração de políticas públicas e a complexificação da agenda de pesquisa no País. Em outros campos, Da Ros (2017, p. 86) também demanda o aperfeiçoamento teórico da pesquisa sobre judicialização da política no Brasil e a importância de se posicionar o STF entre a “constelação imensa e diversificada de órgãos judiciais” no próprio contexto judicial brasileiro e dentro de um contexto global de diálogo com outras cortes.

No âmbito das boas práticas institucionais, cumpre dizer que o Poder Judiciário brasileiro também já possui um histórico recente de aproximação com a opinião pública e de uso de mecanismos de monitoramento e supervisão dos seus julgados. Segundo Vilhena Vieira (2018, p. 166-173), múltiplas foram as escolhas institucionais que levaram a essa exacerbada concentração de poderes na mão do STF, seja a natureza ambiciosa da Constituição de 1988, seja a sobreposição de funções atribuídas ao Tribunal, seja a politização da jurisdição do STF com a criação de amici curiae, entre outros instrumentos. Sobre esse ponto, o diagnóstico preciso de Oscar Vilhena Vieira (2018), da existência de uma "supremocracia”, indica o fortalecimento da autoridade do Judiciário (e das cortes) perante outras esferas de poder e a sociedade ${ }^{16}$.

14 “[...] isso significa que duas das quatro linhas de pesquisa em meio às quais o STF pode ser analisado na área de comparative judicial politics estão mapeadas com relativa clareza na literatura: acesso e impacto. O primeiro pode seguramente ser descrito como bastante amplo, e o segundo como elevado, em parte justamente por causa da amplitude do primeiro" (DA ROS, 2017, p. 83).

15 “[...] desde 1988 mais de 200 dispositivos legais brasileiros foram vetados por decisões definitivas do STF apenas em casos das ADIs. Tal dado, comparado à Suprema Corte norte-americana supera o número de 174 leis federais julgadas inconstitucionais em toda a história e no TCF alemão responsável por declarar inconstitucionais 190 leis federais entre 1951 e 1990” (DA ROS, 2017, p. 78).

16 Cumpre destacar que a formulação do conceito despertou a reflexão mais ampla sobre o impacto das decisões do STF na construção do direito público brasileiro. Sobre isso, cf. SUNDFELD; DOMINGOS (2013). 
A Corte Constitucional brasileira é uma das únicas no mundo que conta com a previsão de uma "TV Justiça”, que divulga ao vivo as sessões de seus julgamentos ${ }^{17}$. Além disso, o STF já conta, há algum tempo, com a possibilidade de participação social direta nos julgamentos. Inclusive, o sucesso das iniciativas de aproximação social criadas pelo STF nos anos de 1990 levou à ampliação da previsão processual, no Código de Processo Civil de 2015, das “audiências públicas” para os casos dos chamados Incidentes de Resolução de Demandas Repetitivas (IRDRs) em tribunais de segunda instância - e a ampliação da admissão dos amici curiae para participação social em todas as instâncias judiciais.

A mudança do perfil de conteúdo das decisões judiciais nos últimos anos, especialmente promovida pelo fenômeno da "judicialização da política", tem fomentado a ambientação da deliberação judicial fora dos circuitos exclusivamente jurídicos. Os casos de grande comoção nacional em direitos civis e políticos, a discussão de temas de controvérsia moral, além dos julgamentos de corrupção provenientes das investigações das operações dos casos “Mensalão”, no princípio dos anos 2000, e, mais recentemente, “Lava Jato” têm estimulado o interesse público no conteúdo e processo deliberativo dos tribunais.

O Poder Judiciário brasileiro tampouco se descuidou, nos últimos anos, da manutenção do respeito à sua autoridade decisória. O longo caminho começou com as leis que implementaram no País mudanças relevantes para a concretização de um controle de constitucionalidade mais amplo na década de 1990 (Leis n 9.868 e nº 9.882, ambas de 1999) ou, antes disso, com a Lei de Ação Civil Pública (Lei $\left.n^{0} 7.347 / 1985\right)$ e outras mudanças normativas que deram maior poder ao Ministério Público e à mobilização legal já da década de 1980.

A constitucionalização do instituto da Reclamação Constitucional ${ }^{18}$ em 1988 pode ser considerada como a consolidação da construção jurisprudencial do STF no estímulo a uma cultura de respeito aos precedentes, cujo controle é agora estendido a todos os tribunais nacionais ${ }^{19}$.

17 Segundo Felipe de Melo Fonte (2016, p. 104-105), "É interessante notar que a ascensão institucional do STF coincide exatamente com os anos que a transmissão das sessões plenárias passou a ocorrer. Enquanto isso, durante essa etapa de sua trajetória institucional, a TV Justiça trouxe à luz as entranhas do STF”.

18 Fruto da construção jurisprudencial do STF que, com o decorrer do tempo, foi sendo incorporada ao texto constitucional (artigo 102, I, “i”, e artigo 103-A, §3 da Constituição Federal - este último inserido pela EC 45/04), a Reclamação Constitucional no STF é regulamentada pelo artigo 13 da Lei 8.038/1990, pelos artigos 156 e seguintes do Regimento Interno da Corte (RISTF) e prevista no art. 988, III do CPC. Além disso, é prevista para as decisões do STJ, no artigo 105, I, "f” da Constituição Federal.

19 A partir do Código de Processo Civil (Capítulo IX - Da Reclamação) o instituto está previsto para reforçar a autoridade de decisões de quaisquer tribunais. O instituto mantém a natureza de ação originária proposta no tribunal e distribuída ao relator que proferiu a decisão ou acórdão cuja tese jurídica não é aplicada ou respeitada em outra ação ou mesmo em outro recurso ainda pendente de julgamento (artigo 989, incisos I e II c/c artigo 992 do CPC/2015). Também caberá reclamação da parte interessada ou do Ministério Público para garantir a observância de precedente proferido em julgamento de casos repetitivos ou em incidente de assunção de competência (art. 988, IV, CPC/2015). 
As últimas reformas processuais, consolidadas no CPC de 2015, também seguem na linha de uma cultura de valorização do precedente, de promoção de integridade e uniformização da volumosa jurisprudência nacional. Da doutrina processual vigente é crescente a preocupação com a eficácia da decisão judicial. Há uma gama de instrumentos à disposição do juiz para fazer valer suas decisões, sempre tomando-se em consideração mecanismos de substituição do executado (subrogação) ou mecanismos de pressão para a atuação do executado (coerção) ${ }^{20}$.

Além disso, muitas das novas estratégias brasileiras de ampliação decisória são novos usos para antigos instrumentos: seja pelo Judiciário - como a mudança jurisprudencial que houve no controle de constitucionalidade por omissão em direção à sua concreção -, seja pela sociedade civil organizada - pelo pedido de admissão de habeas corpus na modalidade coletiva, como o que ocorreu no ano de $2018^{21}$, dentre outras inovações que estão se firmando nos últimos anos. Isso leva organizações da sociedade civil brasileiras a também se engajarem mais fortemente no movimento de fiscalização do cumprimento judicial, em especial no acompanhamento próximo de litígios estratégicos, pela produção de relatórios ${ }^{22}$ e consolidando as informações necessárias para se avançar nesse processo.

Com esse movimento da academia, do Judiciário e das organizações da sociedade civil, o Poder Judiciário brasileiro vem acumulando um nível razoável de confiança social e ampliando sua articulada interação com os demais poderes no âmbito político. Para o aprimoramento do perfil mediador institucional e da capacidade de resolução de tensões decorrentes da democracia constitucional, acredita-se que existem três eixos de iniciativas nos quais o Judiciário brasileiro necessita ainda avançar para dar conta da difícil tarefa de se manter alinhado às expectativas institucionais e sociais e de promover transformações sociais que sejam duradouras. Passa-se a eles.

20 O Código de Processo Civil prevê no seu “Título II - Do Cumprimento da Sentença” meios técnicos de sub-rogação (substitui a vontade do executado) e coerção (tensiona a vontade do executado, exercendo pressão). No caso da defesa do consumidor em juízo, o Código de Defesa do Consumidor reforça os mecanismos sub-rogatórios em seu art. 84, § 5: "Para a tutela específica ou para a obtenção do resultado prático equivalente, poderá o juiz determinar as medidas necessárias, tais como busca e apreensão, remoção de coisas e pessoas, desfazimento de obra, impedimento de atividade nociva, além de requisição de força policial” (BRASIL, 1990b).

21 SUPREMO TRIBUNAL FEDERAL. HC ñ 143.641/SP (20 de fevereiro de 2018) concedido a "Todas as mulheres submetidas à prisão cautelar no sistema penitenciário nacional, que ostentem a condição de gestantes, de puérperas ou de mães com crianças com até 12 anos de idade sob sua responsabilidade, e das próprias crianças” (BRASIL, 2018).

22 A exemplo, o relatório do Instituto Terra, Trabalho e Cidadania sobre a implementação do Marco Legal da Primeira Infância e o HC n ${ }^{\circ}$ 143.641/SP do STF quanto à situação das mulheres encarceradas. Cf. INSTITUTO TERRA, TRABALHO E CIDADANIA (2019) e/ou o relatório da Conectas Direitos Humanos (2019) sobre a decisão do STF relacionada a penas para pequenos traficantes. 


\subsection{COORDENAÇÃO}

Como colocado, já há iniciativas impulsionadas pelo CNJ quanto ao desenvolvimento de relações de coordenação com outras instituições para o monitoramento e avaliação de grandes temáticas caras ao Poder Judiciário, compreendendo inclusive perquirição quanto às circunstâncias de fato anteriores à judicialização. Exemplo significativo nessa linha é o Fórum Nacional da Saúde (Resolução CNJ nº 107, de 6 de abril de 2010) (CONSELHO NACIONAL DE JUSTIÇA, 2010), revestido inclusive de uma dimensão institucionalizada, que pretende prover o Judiciário de uma visão global do problema. Outro exemplo já citado neste artigo é o Observatório, que, segundo informações disponibilizadas, tem como objetivo o aperfeiçoamento da atuação das instituições em ocorrências de grande impacto e repercussão, incluindo a implantação e modernização de rotinas, prioridades, organização, especialização e estruturação dos órgãos competentes de atuação do Poder Judiciário e do Ministério Público (CONSELHO NACIONAL DE JUSTIÇA; CONSELHO NACIONAL DO MINISTÉRIO PÚBLICO, 2020).

Além dessas iniciativas, o CNJ tem atuado há diversos anos em parceria com outras instituições, internas e externas ao Judiciário, para a realização de relatórios de pesquisa, diagnósticos e projetos, resultando num vasto catálogo de temas com aprofundamento técnico e metodológico rigorosos. Entende-se que tais parcerias são centrais para a condução de estudos e iniciativas com perspectivas complementares e para o aprimoramento das informações disponibilizadas pelo órgão a partir do uso de bases de dados compartilhadas.

O esforço de coordenação de iniciativas compartilhadas se torna cada vez mais relevante num cenário de mobilização social pelo Direito (legal mobilization), conforme já mencionado na revisão de literatura norte-americana. Fabíola Fanti (2017, p. 244) afirma que a partir da decisão Brown nos EUA, desenvolveram-se não só as pesquisas que buscavam investigar esse caso em especial, mas também aquelas que procuravam identificar e analisar as táticas de diversos outros movimentos sociais direcionadas ao direito e às cortes, tais como o movimento feminista, ambiental, dos direitos do consumidor, dos direitos dos presos, entre outros.

Esse envolvimento acadêmico com o tema aumentou na medida em que vários movimentos sociais e grupos de interesse passaram a ter estratégias centrais voltadas ao direito e ao Poder Judiciário, com o uso deste espaço de forma mais ativa. O chamado backlash ${ }^{23}$ e a forma de recepção

23 O “backlash” refere-se à reação hostil diante de uma decisão judicial, que busca sua anulação ou reforma - no caso do Legislativo - ou, ainda, que busca torná-la inefetiva - no caso da mobilização social. Cf. ROSENBERG (1991), obra notória que se dedica ao tema, analisando a reação social à decisão da Suprema Corte no caso Brown v. Board of Education, já que estratégias que envolvem litígio, nas palavras do autor, podem representar, em razão do “backlash”, uma “esperança vazia” de reforma substantiva nas políticas públicas. 
dessas decisões pelas comunidades também passaram a ter atenção do mundo acadêmico, de forma a compreender os ganhos e perdas ao longo desse processo. Cardoso (2012, p. 40) coloca que: “[...] o Poder Judiciário está sendo disputado pelos movimentos sociais”, tanto por constituir espaço de disputa de interpretação do Direito e nova rodada de deliberação política, quanto por institucionalmente o Poder Judiciário poder ser objeto de reformas que o tornem mais permeável às demandas sociais.

Entende-se que o Poder Judiciário, ao interagir de forma mais ativa com instituições do sistema de justiça (Ministério Público, defensorias públicas), com as instituições da sociedade civil e com os centros de pesquisa e think tanks especializados nas temáticas de interesse, permite desenvolver uma maior pluralidade argumentativa e de dados, apta a subsidiar a própria atuação judicial antes, durante e depois da relação processual. As parcerias permitem também que se avalie a execução do trabalho das cortes em ação (courts in action), por uma perspectiva externa e coordenada com as preocupações centrais de agenda temática do próprio Judiciário.

\subsection{MONITORAMENTO}

Como visto da experiência norte-americana - e certamente não é distinto o cenário brasileiro -, não se pode ter como certo que decisões judiciais são sempre cumpridas. Consigne-se que o fenômeno do descumprimento, ou mesmo da observância parcial de julgados, pode se dever a um amplo leque de circunstâncias, que vão desde a indeterminação em si do título judicial em execução, passando ainda pelo seu descompasso com a realidade fática sobre a qual ele deverá incidir, até alcançar a resistência pura e simples de alguns ou de todos os destinatários da condenação.

No sistema brasileiro, uma dificuldade adicional que se põe é a baixa normatividade do processo de execução de sentença, ainda construído (não obstante a renovação da ordem processual civil de 2015) tendo em conta predominantemente o conflito individual, cujas providências de execução são únicas, instantâneas e de baixa complexidade ${ }^{24}$.

Experiência distinta se tem, por exemplo, no sistema jurídico colombiano e mexicano, em que se investiu na figura da “jurisdição de seguimento” ou “jurisdição de supervisão” (RODRÍGUEZ GARAVITO; KAUFFMAN, 2014, p. 44, 60), que se ocupa justamente do monitoramento das

\footnotetext{
24 Sobre esse ponto, o relatório “Justiça em Números”, do CNJ, quanto aos indicadores de providências executórias ("gargalos da execução”), refere-se a eles eminentemente em relação à execução fiscal e penal, sem qualquer menção a processos de natureza coletiva (CONSELHO NACIONAL DE JUSTIÇA, 2020).
} 
providências de execução de sentença, que, em litígios de alta complexidade, podem se prolongar no tempo, ou ainda exigir o concurso de vários distintos atores.

Na Colômbia, a Ley n. 472 de 1998 (artigos 27 e 34) ${ }^{25}$ permitiu alguns mecanismos de acompanhamento para o juiz, que transcendem aquelas próprias à simples execução do julgado. Inovadora é a prerrogativa que se reconhece ao juiz de compartilhar o monitoramento desta fase de concretização da ordem, com a designação de comitê compreendendo as partes, a entidade pública encarregada de zelar pelo direito ou interesse coletivo em litígio, o Ministério Público e ainda organizações governamentais com atividades compatíveis com o objeto do julgado. A alternativa permite não só uma ampliação da responsabilidade pelo cumprimento, mas favorece uma ação articulada entre os envolvidos, para a superação de eventuais obstáculos materiais relevantes que possam se apresentar ao cumprimento da decisão.

Além dessa iniciativa legislativa, a Corte Constitucional da Colômbia também apresenta experiências interessantes para o monitoramento de casos, com a criação de órgãos de seguimento de decisões complexas, mobilizando sociedade civil e instituições parceiras para incremento da efetividade decisória. A sala de acompanhamento da decisão de saúde (T-760/2008) foi criada em 2009, portanto já com mais de dez anos de existência, e em outros casos a Corte tem desenvolvido soluções menos dispendiosas e tão eficientes quanto, como é o caso do monitoramento da situação carcerária realizado pela internet ${ }^{26}$.

Em artigo recente, pesquisadores da UniCEUB propuseram como o STF poderia incorporar um modelo de “autos de seguimento" colombiano para monitoramento decisório, para além da já implementada dinâmica de audiências públicas. Segundo os autores é possível pensar na formação de processos de acompanhamento a partir de classes como "petição” ou “comunicação”, previstas no art. 56, IX, do Regimento Interno (CHEVITARESE; SANTOS; GRAÇA, 2019, p. 225).

25 O artigo 34 da Ley 472 de 1998 disciplina que, dentro do prazo estipulado pelo juiz para cumprimento decisório, é mantida sua competência para "tomar as medidas necessárias para a execução da sentença em conformidade com as normas contidas no Código de Processo Civil”, ocasião em que poderá compor um Comitê para a verificação do cumprimento da sentença do qual participam, além do juiz, as partes, a entidade pública encarregada do direito ou interesse coletivo, o Ministério Público e uma organização não governamental com pertinência temática ao caso (COLÔMBIA, 1998, tradução nossa).

26 Além da sala de seguimento para o caso de saúde (“Sala Especial de Seguimiento a la Sentencia T-760 de 2008 ”) e da sala de seguimento para o caso do deslocamento forçado de pessoas ("Sala Especial de Seguimiento en materia de desplazamiento forzado”), em outros casos o seguimento é realizado por juízes de instâncias inferiores, equipes de monitoramento e relatórios públicos do governo, por meio de portais online e outros bancos de dados completamente públicos e de fácil acesso; a exemplo, o website do notório caso sobre estado de coisas inconstitucional no sistema prisional (última atualização decisória pela Sentencia T-762/2015) (COLÔMBIA, 2015), criado pelo Conselho Superior de Política Criminal. 
A proposta oferecida pelos autores é interessante, mas não está livre de preocupação quanto aos custos de alocação e às possibilidades de financiamento dos recursos humanos e materiais que a iniciativa demanda ${ }^{27}$. Além disso, não é imune de críticas a falta de transparência da Corte Constitucional colombiana quanto à seleção de quais julgados terão esse tipo de investimento ${ }^{28}$.

Superadas as questões logísticas e financeiras, entende-se que a essência dos "autos de seguimento” nada mais é que a atuação permanente e contínua de juiz ou comitê especializado, interno ao Judiciário, para monitoramento do cumprimento de ordem judicial, não inovando essencialmente - na ordem jurídica e sendo possível no sistema atual, sem grandes entraves de ordem burocrática. Por isso, tal iniciativa dependeria mais de uma decisão estratégica de alocação de esforços a respeito de como seriam investidos recursos de monitoramento e de quem seria responsável.

Nesse ponto, a estrutura do Observatório parece já compor um contexto favorável para a experimentação institucional - inclusive a defesa do CNJ no monitoramento judicial também é apontada em artigo recente, de Ana Paula Kosak e Estefânia Maria de Queiroz Barboza (2020). As autoras defendem, principalmente, que o CNJ poderia auxiliar como um órgão que promove a deliberação entre os poderes, que sua atuação poderia ajudar na promoção de decisões mais dialógicas, já que poderia provocar o debate entre os poderes (KOZAK; BARBOZA, 2020, p. 191).

Há também outras iniciativas processuais que demonstram a importância de um mecanismo que denuncie e registre o descumprimento de decisões judiciais, tais como o "incidente de descumprimento”, em diversos países da América Latina ${ }^{29}$.

27 No caso do deslocamento forçado usado pelos autores, a Corte Constitucional foi financiada pelo Alto Comissariado das Nações Unidas para os Refugiados (ACNUR) para composição de sua "Sala Especial de Seguimiento" (RODRÍGUEZ GARAVITO; KAUFFMAN, 2014, p. 38-39).

28 Sobre essa questão de seleção de casos que merecem tratamento, há críticas na doutrina colombiana sobre os critérios utilizados pela Corte Constitucional colombiana e sobre o mecanismo de "insistência”. Segundo Jaramillo Sierra e Barreto Rozo (2010, p. 58), o processo de seleção das ações de tutela pela Corte Constitucional colombiana tem se mostrado, cada vez mais, resultado de amostragem aleatória ou de decisão meramente teórica, por oposição a decisões racionais ou estratégicas deste órgão.

29 Chamado de "incidente de descumprimento" no Chile e Equador (LONDOÑO TORO et al., 2009, p. 170), é equivalente ao "incidente de desacato" previsto na Lei da Jurisdição Constitucional da Costa Rica (COSTA RICA, 1989; GAURI; STATON; CULLELL, 2015, p. 778) e ao “incidente de inexecução” previsto no México (FLORES GARCÍA, 2002, p. 45-46) e Colômbia, desde 1998. Nas palavras da Corte Constitucional em 2014: “o incidente [de desacato] é, em essência, um procedimento disciplinar que indaga sobre a responsabilidade subjetiva da autoridade cominada a materializar o amparo e que, por esta via, aspira a incidir sobre o restabelecimento do direito transgredido" (Acción de Tutela, T-252/14 (Corte Constitucional 23 de 04 de 2014) apud BONILLA PRIETO, 2017, p. 106, tradução nossa). Vide Ley 472 de 1998 (COLÔMBIA, 1998, artículo 41). 
Sobre esses instrumentos processuais, ainda que sofram críticas quanto à sua eficácia ${ }^{30}$, e talvez não representem um modelo pronto e acabado para a importação acrítica, eles mesmo assim possuem um efeito simbólico dissuasório do descumprimento, já que a sanção não garante a proteção dos direitos coletivos e, além disso, é muito custosa a comprovação do elemento subjetivo de negligência ou resistência por parte da autoridade, para viabilizar seu uso (BONILLA PRIETO, 2017, p. 107). Além disso, os instrumentos processuais possuem um efeito indireto: servem como um termômetro para a aferição da recorrência do descumprimento e, com isso, do impacto da decisão.

Staton (2010, p. 91), na sua pesquisa sobre impacto da mídia e da opinião pública na atuação da Suprema Corte mexicana, utilizou um conjunto de dados relacionados a incidentes de inexecução para medir o cumprimento decisório. O grande benefício no uso desses dados seria justamente o registro cuidadoso do histórico e do comportamento de descumprimento da decisão. Sobre o uso desse mecanismo, Staton afirma que a instituição utilizou este poder, com forte apelo midiático, contra um agente público de cargo de alto nível apenas uma vez na história, e conseguiu o cumprimento da ordem, porém não é o que normalmente ocorre - a maior parte dos incidentes é ignorada (STATON, 2010, p. 92-93). Segundo apontado, os resultados empíricos da pesquisa são altamente consistentes com um papel político mais contido da Corte, que é sensível às escolhas de publicização de casos e à fragmentação política - quando mais fragmentado o governo, mais agressiva a postura institucional (STATON, 2010, p. 100-101).

\subsection{TRANSPARÊNCIA}

Não se pode negar que há um esforço na literatura brasileira para a incorporação de novos métodos para análise de eficiência do Judiciário, em especial nas suas iniciativas de incremento da transparência e accountability para exercício da função pública. Além do esforço acadêmico e da sociedade civil, é de notório conhecimento que o CNJ também concentra esforços para promover a transformação da gestão da justiça junto aos juízes das diversas instâncias, com a produção de

30 O Grupo de Pesquisa em Direitos Humanos da Universidade de Rosário analisou 431 expedientes de desacato de julgados penais, civis, administrativos, laborais e de família na cidade de Bogotá no ano de 2007 (LONDOÑO TORO et al., 2009). Segundo os dados levantados, o panorama é desalentador em termos de eficácia do incidente: o grau de descumprimento observado é alarmante - em cerca de 30\% dos casos o incidente não resultou em cumprimento (LONDOÑO TORO et al., 2009, p. 184). 
informação detalhadas sobre o seu funcionamento, pela criação de metas e indicadores para os atores e para os processos do universo judicial.

A importância do investimento em indicadores com base tecnológica para avaliação de desempenho judicial é apontada por Fabiana Luci de Oliveira e Luciana Gross Cunha (2020). Segundo as autoras, mesmo que o objetivo da estatística judicial no Brasil tenha sido o acompanhamento de volume de trabalho dos juízes e dos tribunais, é preciso avançar na produção de dados mais consistentes e detalhados, que possam balizar políticas públicas efetivas para os problemas há décadas diagnosticados (OLIVEIRA; CUNHA, 2020).

O relatório anual “Justiça em Números”31 é hoje o principal instrumento de sistematização dos dados de planejamento, gestão e execução da atividade judiciária no Brasil, e incorporou o método chamado Data Envelopment Analysis (DEA), ou Análise Envoltória de Dados, para a composição do indicador sintético Índice de Produtividade Comparada da Justiça (IPC-Jus). Segundo o relatório analítico, a medida busca resumir a produtividade e a eficiência relativa dos tribunais em um escore único, ao comparar a eficiência otimizada com a aferida em cada unidade judiciária - o comparativo é produzido com base no Índice de Produtividade dos Magistrados (IPM), no Índice de Produtividade dos Servidores (IPS), na Despesa Total do Tribunal e na Taxa de Congestionamento (TC) (CONSELHO NACIONAL DE JUSTIÇA, 2019, p. 182).

Segundo a literatura de base citada no relatório do CNJ, o índice, amplamente usado em análise de eficiência no setor público (em especial, nas áreas de educação e saúde), permite novas medidas para o uso estratégico de recursos materiais e humanos - especialmente relacionados à tradicional crítica da má gestão, burocracia ${ }^{32}$. Porém, a eficiência no estudo é tida, tão somente, pela rapidez no andamento dos processos judiciais ${ }^{33}$, e ainda insuficiente para se pensar cumprimento decisório e eficiência do Judiciário. No domínio específico dos litígios de alta complexidade, rapidez

31 "Principal fonte das estatísticas oficiais do Poder Judiciário, anualmente, desde 2004, o Relatório Justiça em Números divulga a realidade dos tribunais brasileiros, com muitos detalhamentos da estrutura e litigiosidade, além dos indicadores e das análises essenciais para subsidiar a Gestão Judiciária brasileira” (CONSELHO NACIONAL DE JUSTIÇA, 2016).

32 Neste mesmo sentido, Luciana Yeung e Paulo Azevedo (2009) concordam que a relativa eficiência do Judiciário varia entre os estados brasileiros, e que a performance das cortes depende menos do nível de recursos humanos e materiais disponíveis e mais de como é feita a alocação desses recursos pelo gestor. Os autores identificam organizações internas específicas, incentivos conferidos, transparência e habilidades de gestão em cada unidade judiciária como os condutores de uma melhor eficiência (YEUNG; AZEVEDO, 2009, p. 28).

33 Em linguagem comum, a eficiência é tida como sinônimo de rapidez no andamento dos processos judiciais. Sob o ponto de vista econômico, uma unidade produtiva (no caso um tribunal) é considerada eficiente se ela for capaz de produzir mais produtos (no caso sentenças, acórdãos, etc.) sem empregar mais de qualquer um dos recursos materiais e humanos disponíveis (no caso juízes, funcionários, computadores, etc.). Esse conceito não difere daquele relacionado com a rapidez, já que um órgão mais eficiente será capaz de produzir uma quantidade maior de sentenças por unidade de tempo (FOCHEZATTO, 2010, p. 3). O autor indica que em estudo futuro poderia eventualmente avaliar a qualidade das decisões - medidas em termos de sua taxa de reversão em instâncias superiores (FOCHEZATTO, 2010, p. 19). 
na decisão não necessariamente expressará a construção de solução adequada; menos ainda, exequível.

Pensando-se eficiência como baixa no número de processos, é possível perceber pelo mesmo relatório que a fase de execução constitui grande parte dos casos em trâmite e configura a etapa de maior morosidade, se considerado o primeiro grau de jurisdição (justiça comum e juizados especiais) ${ }^{34}$. Por isso, mesmo com os indicadores do CNJ e todos os esforços quanto aos processos em fase de execução, os dados permitem a análise do status do processo interna corporis e ainda não se percebe o desenvolvimento de estudos no Brasil focados na análise do que acontece com os processos "uma vez que eles deixam a sala de audiências"35, para usar a famosa expressão de Rodríguez-Garavito (2011, p. 1.674). Ou seja, qual o grau de eficiência do Judiciário para a resolução de litígios, em termos concretos?

Como sugestão deste trabalho, haveria a necessidade de um novo tópico, adicional à análise das execuções, que seria o monitoramento das decisões judiciais. A equipe "Justiça em Números”, do CNJ, assim como o STF, poderia capitanear uma iniciativa ad hoc de monitoramento, ainda que os dados necessitem de um aprofundamento e coleta mais ampla, com recursos externos mediante parcerias, especialmente nos casos de direitos sociais e políticas públicas que dependem de cumprimento por agentes públicos. A valorização da fase de execução de sentença como providência jurisdicional de mesma relevância que a sentença no processo de conhecimento impulsionará naturalmente esses feitos.

Como externalidades positivas, apenas o lançamento de uma iniciativa dessa natureza já apresentou impactos positivos em experiências externas, como é o caso do controle de cumprimento decisório experimentado na Corte Constitucional da Costa Rica em 2009 - resultando numa diminuição de aproximadamente dois meses de prazo para o cumprimento decisório (GAURI; STATON; CULLELL, 2013, p. 8). Segundo os autores, como, dado o volume de ações, grande parte delas têm pouca visibilidade (low stakes constitutional review), a ampla divulgação da iniciativa pressionou os agentes públicos a cumprirem as decisões, gerando resultados surpreendentes (GAURI;

34 Se observada a $15^{\mathrm{a}}$ edição do relatório "Justiça em Números”, a seção que trata da pós-decisão diz respeito exclusivamente aos "Gargalos da Execução" e indica as execuções fiscais como grandes barreiras de efetividade. Segundo informado, o Poder Judiciário contava com um acervo de 79 milhões de processos pendentes de baixa no final do ano de 2018 , sendo que mais da metade desses processos $(54,2 \%)$ se referia à fase de execução (CONSELHO NACIONAL DE JUSTIÇA, 2019, p. 126).

35 “O que acontece com as ordens contidas nesses julgamentos uma vez que deixam a Sala de Audiências? Em que medida os agentes públicos cumprem as decisões judiciais e adotam medidas tendentes à proteção de direitos econômicos e sociais? Qual impacto essas decisões produzem no Estado, na sociedade civil, nos movimentos sociais e na opinião pública? Por fim, em que medida contribuem para a realização desses direitos?” (RODRÍGUEZGARAVITO, 2011, p. 1.674, tradução nossa). 
STATON; CULLELL, 2013, p. 9). A preocupação do estudo, muito alinhada com o contexto brasileiro, é com os casos de pouca visibilidade, e uma iniciativa de monitoramento de cumprimento decisório atua exatamente nesta zona cinzenta, em razão do comportamento de agentes públicos nesses casos.

\section{CONCLUSÃO}

Na obra “Guía para implementar decisiones sobre derechos sociales”, César Rodríguez Garavito e Celeste Kauffman (2014, p. 7) afirmam que gerações anteriores de defensores de direitos humanos, juízes, gestores de políticas públicas e funcionários de organizações internacionais trabalharam arduamente para garantir o reconhecimento de direitos socioeconômicos que fossem exigíveis ante tribunais nacionais e internacionais.

Em alguma medida, a luta dos ativistas foi exitosa e a inclusão desses direitos na Declaração Universal dos Direitos Humanos das Nações Unidas em 1966 representou só o começo de uma longa trajetória de reconhecimento dos direitos econômicos e sociais em diversos instrumentos internacionais e constituições mundo afora. Não obstante a luta pelo reconhecimento dos direitos, hoje o desafio que se apresenta aos operadores desse amplo sistema é a implementação destas garantias na prática, que remete a uma responsabilidade conjunta de juízes, promotores, advogados, funcionários de direitos humanos e sociedade civil.

Como foi possível identificar no presente trabalho, há uma intensa produção acadêmica e jurisprudencial sobre o cumprimento de decisões judiciais no mundo desde a década de 1950, em especial nos Estados Unidos e na América Latina, fenômeno que não se verifica no Brasil. Sendo assim, o presente artigo procurou sistematizar essas iniciativas e integrar as perspectivas de coordenação, monitoramento e transparência como eixos condutores de uma atuação judicial pautada por sua eficiência e com o olhar voltado para a transformação social.

Conclui-se, a partir da moldura analítica proposta, que existe a necessidade de um maior investimento nos estudos e práticas sobre cumprimento decisório e efetividade judicial no Brasil, para além das perspectivas mencionadas no campo processual. Em termos institucionais e para viabilizar esses estudos, também é urgente que o Poder Judiciário brasileiro incremente a sua coleta e gestão de dados relacionados ao cumprimento decisório (e.g., no caso no Conselho Nacional de Justiça, uma reforma do instrumento “Justiça em Números”) e que crie oportunidades institucionais de aprofundamento empírico e teórico sobre o tema, a exemplo do mencionado Observatório Nacional sobre Questões Ambientais, Econômicas e Sociais de Alta Complexidade e Grande Impacto e 
Repercussão. Revelou-se, nesse sentido, a subnotificação dos casos de descumprimento judicial e o baixo esforço institucional e acadêmico na conceitualização e métrica dessas situações.

Cumpre ainda dizer que qualquer nível de descumprimento de decisões judiciais implica um custo elevado para ambos os lados - partes, atores políticos e judiciais. Por isso, as estratégias normativas devem se aproveitar desses distintos incentivos estratégicos e dos custos, de forma a evidenciar o descumprimento via procedimento específico, tornando-o dado concreto. A mera transparência e accountability quanto ao descumprimento por si só já seria um passo para a aderência da opinião pública - que muitas vezes nem sequer tem notícia do descumprimento decisório, dada a limitada produção desse tipo de informação - ao conteúdo da decisão.

\section{REFERENCIAS}

BARNES, Jeb. Bringing the Courts Back In: Interbranch Perspectives on the Role of Courts in American Politics and Policy Making. Annual Review of Political Science, [s. l.], v. 10, n. 1, p. 25-43, 2007. Disponível em: https://bit.ly/3bttaU1. Acesso em: 7 jan. 2020.

BARTLEY, Numan V. The rise of massive resistance: Race and politics in the South during the 1950’s. 1. ed. Louisiana: Louisiana State University Press, 1969.

BAUM, Lawrence. Implementation of Judicial Decisions: an organizational analysis. American Politics Research, [s. l.], v. 4, n. 1, p. 86-114, 1976.

BAUM, Lawrence. The Supreme Court in American Politics. Annual Review of Political Science, [s. l.], v. 6, p. 161-180, 2003. Disponível em: https://bit.ly/3qwY0zo. Acesso em: 7 jan. 2020.

BONILLA PRIETO, Anamaría. Retos y alcances de los mecanismos de seguimiento a las decisiones proferidas en los procesos de acción popular. Revista Temas Socio-Jurídicos, [s. l.], v. 36, n. 72, p. 101-128, jan./jun. 2017.

BRASIL. Constituição da República Federativa do Brasil de 1988. Disponível em: https://bit.ly/3bweF1U. Acesso em: 18 jan. 2020.

BRASIL. Emenda Constitucional $\mathbf{n}^{\mathbf{0}}$ 45, de 30 de dezembro de 2004. Altera dispositivos dos arts. $5^{\circ}$, 36, 52, 92, 93, 95, 98, 99, 102, 103, 104, 105, 107, 109, 111, 112, 114, 115, 125, 126, 127, 128, 129, 134 e 168 da Constituição Federal, e acrescenta os arts. 103-A, 103B, 111-A e 130-A, e dá outras providências. Disponível em: https://bit.ly/3qu0Sx5. Acesso em: 18 jan. 2020.

BRASIL. Lei no 13.105, de 16 de março de 2015. Código de Processo Civil. Disponível em: https://bit.ly/3l05JVR. Acesso em: 18 jan. 2020.

BRASIL. Lei $\mathbf{n}^{0}$ 7.347, de 24 de julho de 1985. Disciplina a ação civil pública de responsabilidade por danos causados ao meio-ambiente, ao consumidor, a bens e direitos de valor artístico, estético, 
histórico, turístico e paisagístico (VETADO) e dá outras providências. Disponível em: https://bit.ly/2PCwCTV. Acesso em: 18 jan. 2020.

BRASIL. Lei $\mathbf{n}^{\mathbf{0}} \mathbf{8 . 0 3 8}$, de 28 de maio de 1990. Institui normas procedimentais para os processos que especifica, perante o Superior Tribunal de Justiça e o Supremo Tribunal Federal. 1990a. Disponível em: https://bit.ly/3cdM80c. Acesso em: 18 jan. 2020.

BRASIL. Lei no 8.078, de 11 de setembro de 1990. Dispõe sobre a proteção do consumidor e dá outras providências. 1990b. Disponível em: https://bit.ly/3cjsbFp. Acesso em: 18 jan. 2020.

BRASIL. Lei $\mathbf{n}^{0} \mathbf{9 . 8 6 8}$, de 10 de novembro de 1999. Dispõe sobre o processo e julgamento da ação direta de inconstitucionalidade e da ação declaratória de constitucionalidade perante o Supremo Tribunal Federal. Disponível em: https://bit.ly/2OiOEKL. Acesso em: 18 jan. 2020.

BRASIL. Lei $\mathbf{n}^{\mathbf{0}} \mathbf{9 . 8 8 2}$, de 3 de dezembro de 1999. Dispõe sobre o processo e julgamento da argüição de descumprimento de preceito fundamental, nos termos do § 10 do art. 102 da Constituição Federal. Disponível em: https://bit.ly/3v92mjR. Acesso em: 18 jan. 2020.

BRASIL. Supremo Tribunal Federal (STF). Habeas Corpus $n^{0}$ 143.641/SP. Relator: Min. Ricardo Lewandowski. Segunda Turma. Data de julgamento: 20/02/2018. Disponível em: https://bit.ly/38ng4pJ. Acesso em: 12 jan. 2020.

BRASIL. Supremo Tribunal Federal (STF). Regimento Interno. Atualizado até a Emenda Regimental n. 57/2020. Brasília: STF, Secretaria de Documentação, 2020. 268 p. Disponível em: https://bit.ly/3vbn1ni. Acesso em: 18 jan. 2020.

CANON, Bradley C. Reactions of State Supreme Courts to a U.S. Supreme Court Civil Liberties Decision. Law \& Society Review, [s. l.], v. 8, n. 1, p. 109-134, 1973.

CARDOSO, Evorah Lusci Costa. Cortes supremas e sociedade civil na América Latina: estudo comparado Brasil, Argentina e Colômbia. 134 f. Tese (Doutorado em Direito) - Faculdade de Direito, Universidade de São Paulo, São Paulo, 2012.

CHEVITARESE, Aléssia Barroso Lima Brito Campos; SANTOS, Ana Borges Coêlho; GRAÇA, Felipe Meneses. A efetividade do estado de coisas inconstitucional em razão dos sistemas de monitoramento: uma análise comparativa entre Colômbia e Brasil. Revista Brasileira de Políticas Públicas, [s. l.], v. 9, n. 2, 2019.

COLÔMBIA. Congresso da República. Ley 472 de 1998 Nivel Nacional. Por la cual se desarrolla el artículo 88 de la Constitución Política de Colombia en relación con el ejercicio de las acciones populares y de grupo y se dictan otras disposiciones. 1998. Disponível em: https://bit.ly/38lQtxq. Acesso em: 18 jan. 2020.

COLÔMBIA. Consejo Superior de Política Criminal. Sentencia-T-762-de-2015. La Corte Constitucional reiteró el estado de cosas inconstitucional en materia penitenciaria y carcelaria y profirió órdenes generales y específicas a las entidades concernidas con el cumplimiento y superación de esta problemática. 2015. Disponível em: https://bit.ly/3rxZjzt. Acesso em: 13 jul. 2019. 
CONECTAS DIREITOS HUMANOS. Prisão a qualquer custo: Como o Sistema de Justiça descumpre decisão do STF sobre penas para pequenos traficantes. 1. ed. São Paulo: Conectas, 2019.

CONSELHO NACIONAL DE JUSTIÇA (CNJ). Justiça em Números 2019. Brasília, 2019. Disponível em: https://bit.ly/38mBtiC. Acesso em: 7 jan. 2020.

CONSELHO NACIONAL DE JUSTIÇA (CNJ). Justiça em Números 2020: ano-base 2019. Disponível em: https://bit.ly/3rxXzGm. Acesso em: 10 abr. 2020.

CONSELHO NACIONAL DE JUSTIÇA (CNJ). Portal CNJ. Justiça em Números. [Brasília], 26 abr. 2016. Disponível em: https://bit.ly/3sEknWk. Acesso em: 7 jan. 2020.

CONSELHO NACIONAL DE JUSTIÇA (CNJ). Resolução No 107 de 06/04/2010. Institui o Fórum Nacional do Judiciário para monitoramento e resolução das demandas de assistência à saúde. Disponível em: https://bit.ly/3ca9Lqw. Acesso em: 9 abr. 2020.

CONSELHO NACIONAL DE JUSTIÇA (CNJ); CONSELHO NACIONAL DO MINISTÉRIO PÚBLICO (CNMP). Observatório Nacional sobre Questões Ambientais, Econômicas e Sociais de Alta Complexidade e Grande Impacto e Repercussão. 2020. Disponível em: https://bit.ly/3bsJAfp. Acesso em: 22 out. 2020.

COSTA RICA. La Asamblea Legislativa de la Republica de Costa Rica. Ley de la Jurisdicción Constitucional $\mathbf{n}^{\mathbf{0}}$ 7135. 5 out. 1989. Disponível em: https://bit.ly/3vbo2f6. Acesso em: 10 abr. 2020.

DA ROS, Luciano. Em que ponto estamos? Agendas de pesquisa sobre o Supremo Tribunal Federal no Brasil e nos Estados Unidos. In: ENGELMANN, Fabiano (org.). Sociologia política das instituições judiciais. Porto Alegre: Editora da UFRGS/CEGOV, 2017. p. 57-97.

DALY, Tom Gerald. Democratic Decay: Conceptualising an Emerging Research Field. Hague Journal on the Rule of Law, [s. l.], v. 11, p. 9-36, 2019.

EASTON, Robert E. The Dual Role of the Structural Injunction. Yale Law Journal, [s. l.], v. 99, n. 8, p. 1.983-2.002, 1990.

ENGELMANN, Fabiano; BANDEIRA, Júlia Veiga Vieira Mancio. Judiciário e Política na América Latina: Elementos para uma Análise Histórico-Política de Argentina, Brasil, Chile, Colômbia e Venezuela. In: ENGELMANN, Fabiano (org.). Sociologia política das instituições judiciais. Porto Alegre: Editora da UFRGS/CEGOV, 2017. p. 197-220.

ESTADOS UNIDOS DA AMÉRICA. US Supreme Court. Brown v. Board of Education of Topeka, 347 U.S. 483 (1954). Disponível em: https://bit.ly/3emMLqV. Acesso em: 22 jan. 2020.

FANTI, Fabíola. Movimentos Sociais, Direito e Poder Judiciário: um encontro teórico. In: ENGELMANN, Fabiano (org.). Sociologia política das instituições judiciais. Porto Alegre: Editora da UFRGS/CEGOV, 2017. p. 241-274.

FLORES GARCÍA, Mario Alberto. Cumplimiento y ejecución de las sentencias de amparo. Posibilidad de imponer multas y registrar antecedentes en el expediente personal, para el caso de 
reincidencia de la autoridad omisa. Revista del Instituto de la Judicatura Federal, [s. l.], n. 10, p. 39-56, 2002. Disponível em: https://bit.ly/3emGiMI. Acesso em: 20 out. 2019.

FOCHEZATTO, Adelar. Análise da eficiência relativa dos tribunais da justiça estadual brasileira utilizando o método DEA. XXXVI Reunion de Estudios Regionales - AECR, Badajoz, 17-19 nov. 2010.

FONTE, Felipe de Melo. Jurisdição constitucional e participação popular: O Supremo Tribunal Federal na era da TV Justiça. 1. ed. Rio de Janeiro: Lumen Juris, 2016.

FRIEDMAN, Lawrence M. Impact: how law affects behavior. London: Harvard University Press, 2016.

GAURI, Varun; STATON, Jeffrey K.; CULLELL, Jorge Vargas. A Public Strategy for Compliance Monitoring. World Bank Policy Research Working Paper n. 6523, [s. l.], 1 jun. 2013. Disponível em: https://bit.ly/3bsu3MS. Acesso em: 7 jan. 2020.

GAURI, Varun; STATON, Jeffrey K.; CULLELL, Jorge Vargas. The Costa Rican Supreme Court's Compliance Monitoring System. The Journal of Politics, [s. l.], v. 77, n. 3, p. 774-786, jul. 2015.

HALL, Matthew. The Nature of Supreme Court Power. New York: Cambridge University Press, 2011.

HALL, Matthew. The Semiconstrained Court: Public Opinion, the Separation of Powers, and the U.S. Supreme Court's fear of nonimplementation. American Journal of Political Science, [s. l.], v. 58, n. 2, p. 352-366, abr. 2014.

HOROWITZ, Donald L. The Courts and Social Policy. Washington: Brookings Institution Press, 1977.

HUNTINGTON, Samuel. A terceira onda: a democratização no final do século XX. São Paulo: Ática, 1994.

INSTITUTO TERRA, TRABALHO E CIDADANIA (ITTC). MaternidadeSemPrisão. Diagnóstico da aplicação do Marco Legal da Primeira Infância para o desencarceramento de mulheres. São Paulo: ITTC, 2019. Disponível em: https://bit.ly/3vbqaU6. Acesso em: 7 jan. 2020.

ISSACHAROFF, Samuel. Fragile Democracies: contested power in the era of Constitutional Courts. New York: Cambrigde University Press, 2015.

JARAMILLO SIERRA, Isabel Cristina; BARRETO ROZO, Antonio. El problema del procesamiento de información en la selección de tutelas por la Corte Constitucional, con especial atención al papel de las insistencies. Colombia Internacional, [s. l.], v. 72, p. 53-86, jul./dez. 2010.

JOHNSON, Richard M. The dynamics of compliance: Supreme Court decision-making from a new perspective. Evanston, IL: Northwestern University Press, 1967. 
KAPISZEWSKI, Diana; TAYLOR, Matthew M. Compliance: conceptualizing, measuring, and explaining adherence to judicial rulings. Law \& Social Inquiry, [s. l.], v. 38, n. 4, p. 803-835, 2013.

KOSAK, Ana Paula; BARBOZA, Estefânia Maria de Queiroz. O papel do CNJ diante do reconhecimento do estado de coisas inconstitucional do sistema carcerário brasileiro na perspectiva do ativismo dialógico. Revista Brasileira de Políticas Públicas, Brasília, v. 10, n. 1, p. 175-194, 2020.

LANÇADO no STF site desenvolvido em parceria entre CNJ e CNMP para monitorar processos de grande repercussão. Supremo Tribunal Federal, Notícias STF, 2 maio 2019. Disponível em: https://bit.ly/3qAbs5z. Acesso em: 21 jun. 2019.

LONDOÑO TORO, Beatriz et al. Eficacia del incidente de desacato: estudio de caso, Bogotá, Colombia (2007). Vniversitas, [s. l.], v. 58, n. 118, p. 161-187, 2009. Disponível em: https://bit.ly/3zfXHyf. Acesso em: 11 jan. 2020.

MAVEETY, Nancy L. The Pioneers of Judicial Behavior. Ann Arbor, MI: University of Michigan Press, 2002.

MOLHANO RIBEIRO, Leandro; WERNECK ARGUELHES, Diego. Contextos da judicialização da política: novos elementos para um mapa teórico. Revista Direito GV, São Paulo, v. 15, n. 2, e1921, 2019. Disponível em: https://bit.ly/3rwOTAe. Acesso em: 24 dez. 2019.

MUIR JR., William K. Prayer in the Public Schools: Law and Attitude Change. Chicago: The University of Chicago Press, 1967.

OLIVEIRA, Fabiana Luci de; CUNHA, Luciana Gross. Os indicadores sobre o Judiciário brasileiro: limitações, desafios e o uso da tecnologia. Revista Direito GV, São Paulo, v. 16, n. 1, e1948, 2020. Disponível em: https://bit.ly/38nIXC5. Acesso em: 22 out. 2020.

PELTASON, Jack W. Fifty-Eight Lonely Men: Southern Federal Judges and School Desegregation. Champaign, IL: University of Illinois Press, 1971.

RÍOS-FIGUEROA, Julio. Constitutional courts as mediators: Armed conflict, civil-military relations, and the rule of law in Latin America. New York: Cambridge University Press, 2016.

RODRÍGUEZ GARAVITO, César; KAUFFMAN, Celeste. Guía para implementar decisiones sobre derechos sociales. Estrategias para jueces, funcionarios y activistas. Documentos 17. Bogotá: DeJusticia, 2014. Disponível em: https://bit.ly/38meMek. Acesso em: 11 jan. 2020.

RODRÍGUEZ-GARAVITO, César. Beyond the courtroom: The impact of judicial activism on socioeconomic rights in Latin America. (Symposium: Latin American Constitutionalism). Texas Law Review, [s. l.], v. 89, n. 7, p. 1.669-1.698, 2011.

ROSENBERG, Gerald N. The hollow hope: Can courts bring about social change? Chicago: University of Chicago Press, 1991. 
STATON, Jeffrey K. Judicial Power and Strategic Communication in Mexico. New York: Cambridge University Press, 2010.

SUNDFELD, Carlos Ari; DOMINGOS, Liandro. Supremocracia ou administrocracia no novo direito público brasileiro? In: ALMEIDA, Fernando Dias Menezes de et al. (coord.). Direito público em evolução: estudos em homenagem à Professora Odete Medauar. Belo Horizonte: Fórum, 2013. p. 31-38.

TUSHNET, Mark. Symposium: Brown v. Board of Education and its legacy: A tribute to Justice Thurgood Marshall, Public Law Litigation and the Ambiguities of Brown. Fordham Law Review, [s. l.], v. 61, n. 1, p. 23-28, 1992. Disponível em: https://bit.ly/30oo1q6. Acesso em: 21 jun. 2019.

VILHENA VIEIRA, Oscar. A Batalha dos Poderes: da transição democrática ao mal-estar constitucional. 1. ed. São Paulo: Companhia das Letras, 2018.

WERnECK VIANNA, Luiz et al. A Judicialização da Política e das Relações Sociais no Brasil. Rio de Janeiro: Revan, 1999.

WESTERLAND, Chad et al. Strategic Defiance and Compliance in the U.S. Courts of Appeals. American Journal of Political Science, [s. l.], v. 54, n. 4, p. 891-905, out. 2010. Disponível em: https://bit.ly/38r5lKV. Acesso em: 11 jan. 2020.

YEUNG, Luciana Luk-Tai; AZEVEDO, Paulo Furquim de. Beyond Conventional Wisdom and Anecdotal Evidence: Measuring Efficiency of Brazilian Courts. $13^{\text {th }}$ annual conference of the International Society for New Institutional Economics - ISNIE. Berkeley: University of California, 2009. Disponível em: https://bit.ly/3qubdZV. Acesso em: 11 jan. 2020. 